\title{
Mineralogy, geochemistry and geological occurrence of supergene manganese ore mineralization in North West Province, South Africa
}

\author{
Benedick Kinshasa Pharoe $^{1}$, A. N. Evdokimov ${ }^{1}$, I. M. Gembitskaya ${ }^{1}$, Christopher Baiyegunhi ${ }^{2}$, and \\ Zusakhe Nxantsiya ${ }^{3}$
}

Received 24 November 2019; accepted 3 Febuary 2020; published 22 August 2020.

The Northwest manganese mineralization comprises of supergene ores developed in a weathering crust of the Neoarchean manganiferous dolostones of the Transvaal Supergroup. These are near-surface accumulation of manganese wad and nodules. The manganese wad is preserved in a typical karstic structures on top of the weathered manganiferous dolostones within the Waterval Saprolite. The saprolite is in turn overlain with a sharp erosional contact by West-wits alluvium hosting manganese nodules. Ore formation is attributed to in-situ surficial weathering, partial dissolution and leaching of ore substances from the manganiferous dolostones. These combined processes led to the release of $\mathrm{Mn}$ and Fe rich colloidal particles into the overlying water column of the depository, which later precipitated as manganese nodules upon interaction with alluvial sediments which acted as substrates and centers of accretion. This study presents results on the mineralogy, geochemical constituents and geological occurrence of the ore mineralization. Mineralogical studies indicated the occurrence of romanechite, cryptomelane and galaxite as predominant manganese oxide phases, and pyrolusite and vernadite occurring in minute quantities. Geochemical and mineralogical data anomalies obtained in this study were used to develop a genetic classification of the ore deposit. On the basis of trace element geochemistry applied in this study coupled with studies of mineralogical and diagenetic features of the samples, different manganese classification schemes were adopted and inferences were made from the data interpretation which indicated supergene and hydrogenetic nature of the ore mineralization suggesting precipitation of ore substances from the weathered Mn colloids in a supergene zone. KEYWORDS: Supergene manganese ores; mineralogy; geochemistry; ore occurrence; romanechite; General Mine; weathering crust.

Citation: Pharoe, Benedick Kinshasa, A. N. Evdokimov, I. M. Gembitskaya, Christopher Baiyegunhi, and Zusakhe Nxantsiya (2020), Mineralogy, geochemistry and geological occurrence of supergene manganese ore mineralization in North West Province, South Africa, Russ. J. Earth. Sci., 20, ES5003, doi:10.2205/2020ES000703.

\section{Introduction}

\footnotetext{
${ }^{1}$ Saint Petersburg Mining University, St. Petersburg, Russia

${ }^{2}$ Department of Physics and Geology, University of Limpopo, Limpopo, South Africa

${ }^{3}$ Council for Geosciences, Pretoria, South Africa

Copyright 2020 by the Geophysical Center RAS. http://rjes.wdcb.ru/doi/2020ES000703-res.html
}

The North West Province of the Republic of South Africa has recently received a tremendous amount of attention following a discovery of a number of small scale manganese ore mineralization in a weathering crust on top of the Neoarchean manganiferous carbonate platform of the Transvaal Basin. This region is located within an ancient 
African erosional surfaces termed African 1 and African 2 surfaces of erosion which are estimated to have started developing during the late Cretaceous period in post-Gondwana times [Vafeas et al., 2018, 2019. The widespread mineralization of secondary manganese oxide and oxyhydroxides is evident mostly in the form of barium and potassium-bearing manganese mineral phases across the latter platform which stretches from the town of Krugersdorp in the east to the town of Mafikeng in the west. The ore occurs in the form of manganese wad and nodules. The first discovery of this mineralization was made by Dr. De Villiers of the former Geological Survey of the Union of South Africa. He noted that these deposits were found exclusively in the areas of lower rainfall in the more westerly portion of the province, roughly west of longitude $28^{\circ}$ east on the geological map of the republic. His study involved selection of 5 samples across the manganiferous dolomite sections in different intervals around the Krugersdorp area which were later analyzed for geochemical components. On the basis of the analyzed samples he came to a conclusion that the dolomites contained a relatively high content of manganese (up to $7.5 \mathrm{wt} \%$ ) and can therefore represent protores from which the overlying supergene mineralization was derived [De Villiers, 1960]. Later a number of authors opened a research in the region where these deposits were studied in Ryedale Mine near the town of Ventersdorp and in the West-Wits Mine near Krugersdorp [Beukes et al., 1999, Gutzmer and Beukes, 1994, Pack et al., 2000, Van Niekerk et al., 1999a, 1999b. Their studies led to the discovery of a new deposit being hosted by the Permian Ecca strata of the Karoo Supergroup in Ryedale mine. The deposit in Ryedale mine was described to contain well-preserved imprints of Glossopteris leaves on the bedding planes of the wad [Pack et al., 2000 which prompted a conclusion that the Ecca strata may have also played a major role in contribution towards the formation of manganese wad in the area. Therefore, De Villiers's ore genetic model had to be modified to include this newly discovered kind of ore deposit.

Most of the research which was carried out in the North West region previously was mainly focused on studying the mineral constituents of manganese wad and therefore less attention was given to the manganese nodules mineralization in the overly- ing alluvium as they were often regarded as simply gravels coated with Mn oxyhydroxides [Beukes et al., 1999, Gutzmer and Beukes, 1994; Pack et al., 2000. Van Niekerk et al., 1999a. 1999b. Results on mineral composition of the wad have shown that the wad comprised mainly of cryptomelane and pyrolusite and other accessory minerals such as kaolinite, silica. Most recent study on the North West Manganese Ore Deposit was carried by us [Pharoe and Liu, 2018. Our study included opening of several exploration pits in one of the selected area that is under development. This was executed in order to fully understand the ore distribution and occurrence across the area. Our work managed to provide a detailed stratigraphy of the ore deposit. The study included creation and mapping of the geological cross-section and deciphering the relationship between the underlying manganiferous dolomites, manganese wad and manganese nodules; and tracing of erosional unconformities which marks the development and erosion of ancient landscapes.

The current work was inspired by lack of data present on the geochemistry, mineralogy and a comprehensive geologic model defining the processes which influenced the ore mineralization in the areas under study. It is therefore the aim of this study to present mineral composition, geochemistry and ore occurrence of the North West manganese wad and nodule deposit. The samples used in this study were collected from different areas of mineralization across the province. However, the greatest amount of data upon which analyses were performed was collected from the open pit areas in the General Nice Manganese Mine in Ventersdorp (Figure 1).

\section{Geological Setting of the Study Area}

The Highveld region of the Republic of South Africa occupies the north-western flank of the Kaapvaal Craton. The Craton is composed mainly of old cratonic trondjhemite-tonalite suite of granitic and gneissic rocks intruding into mafic-ultrabasic greenstones and carbonates (Figure 2). The manganese deposits in this area is commonly confined to ancient karstic depression underlain by Neoarchean carbonate platform of the Malmani Subgroup, 


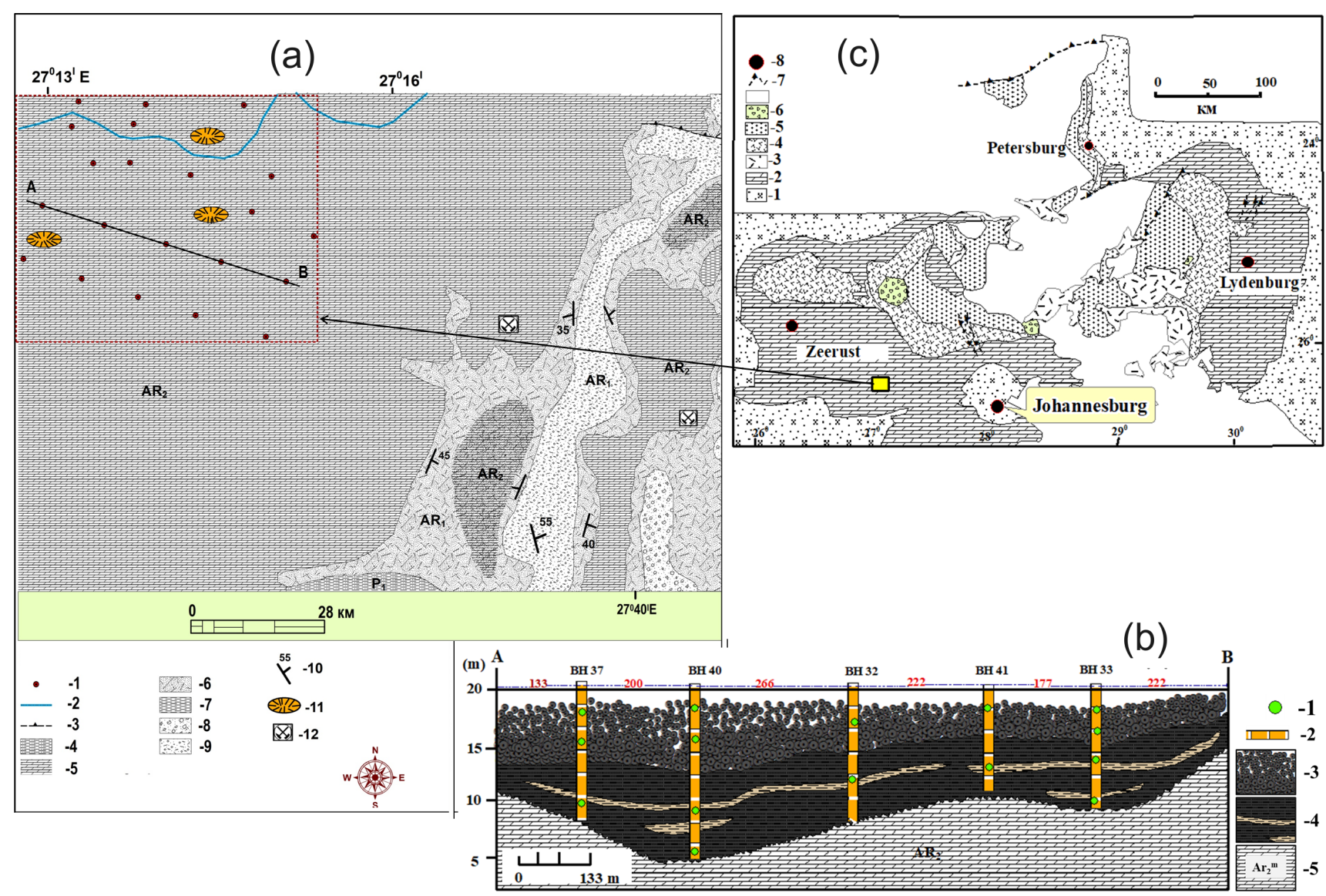

Figure 1. Geological structure and section of the North-West managnese Deposit, South Africa: (a), 1 - exploration pits, 2 - sinkholes (P), 3 - faults, 4 - paleochannels , 5 - shales (P1), 6 - manganiferous Malmani Dolomites $\left(\mathrm{Ar}_{2}^{m}\right), 7$ - quartzite of the Black Reef $\left(\mathrm{Ar}_{1}\right), 8$ - shales and subordinate sandstones $\left(\mathrm{Ar}_{1}\right), 9$ - gold - bearing conglomerates and subordinate sandstones $\left(\mathrm{Ar}_{1}\right), 10$ - diamictites, conglomerates and Sandstones $\left(\mathrm{Ar}_{1}\right)$. (b), 1 - sampling points, 2 - exploration pits along profile A-B, 3 - manganese nodules $(\mathrm{N}), 4$ - powdered manganese wad with a layer of shale $\left(K_{2}\right), 5$ - manganiferous dolomite $\left(\mathrm{Ar}_{2}^{m}\right)$. (c), 1 - pre-Transvaal formations $\left(\mathrm{Ar}_{1}\right), 2$ - manganiferous Malmani Dolomites $\left(\mathrm{Ar}_{2}^{m}\right), 3$ - Rooiberg felsites (Kr), 4 - mafic rocks of the Bushveld Complex (Kr), 5 granites and granophyres of the Lebowa Granite Suite $(\mathrm{Kr}), 6$ - alkaline complexes post-Bushveld $\left(\mathrm{Rf}_{2}\right), 7$ - faults and 8 -major towns.

Transvaal Supergroup. Most of the Transvaal strata in the region were mainly intruded by the $2.05 \mathrm{Ga}$ emplacement of the Bushveld Complex.

The General Nice Lease forms part of the paleodrainage divide which was noted by Eriksson et al. 2001 in the Highveld region of South Africa. The divide occurs in the form of a watershed between rivers flowing into the Indian and Atlantic oceans and extends from west of Johannesburg to Lichtenberg [Pack et al., 2000; Van Niekerk et al., 1999a, 1999b. The area under study is tectoni- cally characterised by graben-like paleovalleys and eroded horsts within an average surface relief of $1550 \mathrm{~m}$, and represent an ancient drainage confinement of tertiary braided river systems draining alluvial fans on an inferred drainage divide [Els et al., 1995. The inferred trust-faulting tectonism which is characterized by graben like paleovalley structures is mostly ascribed to Proterozoic magmatic intrusions and to a lesser extent the impact of the Vredefort meteorite (Figure 3).

According to [Partridge and Maud, 1987, Pharoe 


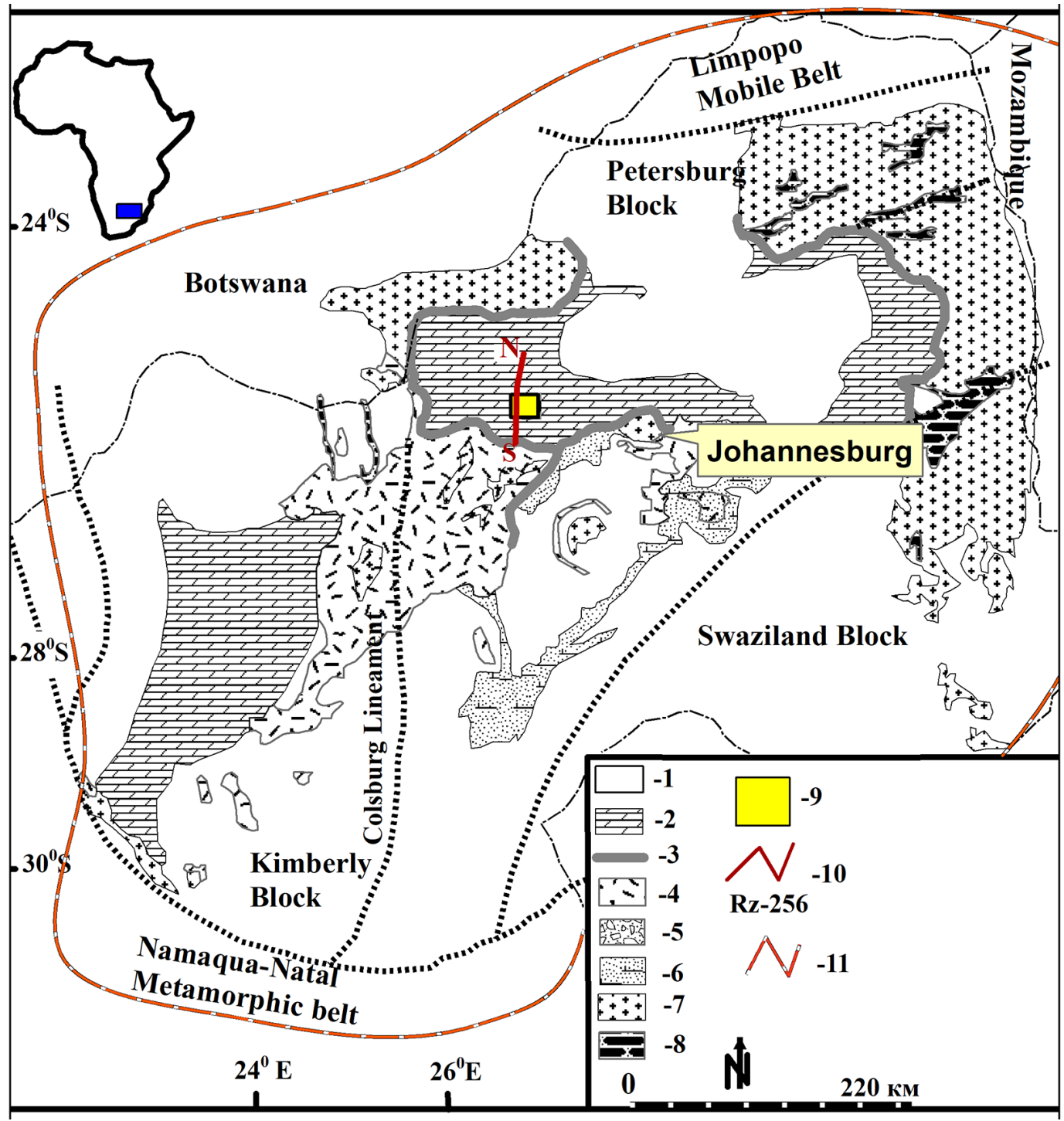

Figure 2. Geological map of the Kaapvaal Craton showing the distribution of surface and subsurface stratigraphic units (after Frimmel, 2014)]: 1 - Supracrustal intrusions (Pr1); 2 - Neoarchean manganiferous dolostones $\left(\mathrm{Ar}_{2}\right) ; 3$ - Quartzite of the Black Reef Formation $\left(\mathrm{Ar}_{1}\right) ; 4$ - Ventersdorp lava $\left(\mathrm{Ar}_{1}\right) ; 5$ - Conglomerate, shale and subordinate sandstones of the upper Witwatersrand $\left(\mathrm{Ar}_{1}\right) ; 6$ - Quartzites, shales and the subordinate conglomerate of the lower Witwatersrand $\left(\mathrm{Ar}_{1}\right) ; 7$ - Archean granitoids $\left(\mathrm{Ar}_{1}\right) ; 8$ - Archean greenstones $\left(\mathrm{Ar}_{1}\right) ; 9$ - Study area; 10 - Seismic profile running through the study; 11 - Inferred extension of the Kaapvaal craton.

and Liu, 2018 the paleodrainage divide represent a relic of the weathered ancient post-Gondwana land surface along Highveld region in the north-western province and constitutes of Neoarchean manganiferous carbonates, manganese nodules and wad, and subordinate outcrops of quartzite and malachite in the area [Partridge and Maud, 1987, Pharoe and Liu, 2018 (Figure 4). The lithostratigraphic profile of the region is characterized by basal Neoarchean manganiferous dolostone, and this is in turn overlain by Waterval saprolite in a typically karst setting on top of the weathered stromatolitic pinnacles (Figure 1b). Manganese wad forms part of the saprolite and is overlain with sharp erosional surface by an alluvial succession known as the West-wits alluvium which hosts manganese nodules [Pharoe and Liu, 2018, Van Niekerk et al., 1999a. 1999b. 


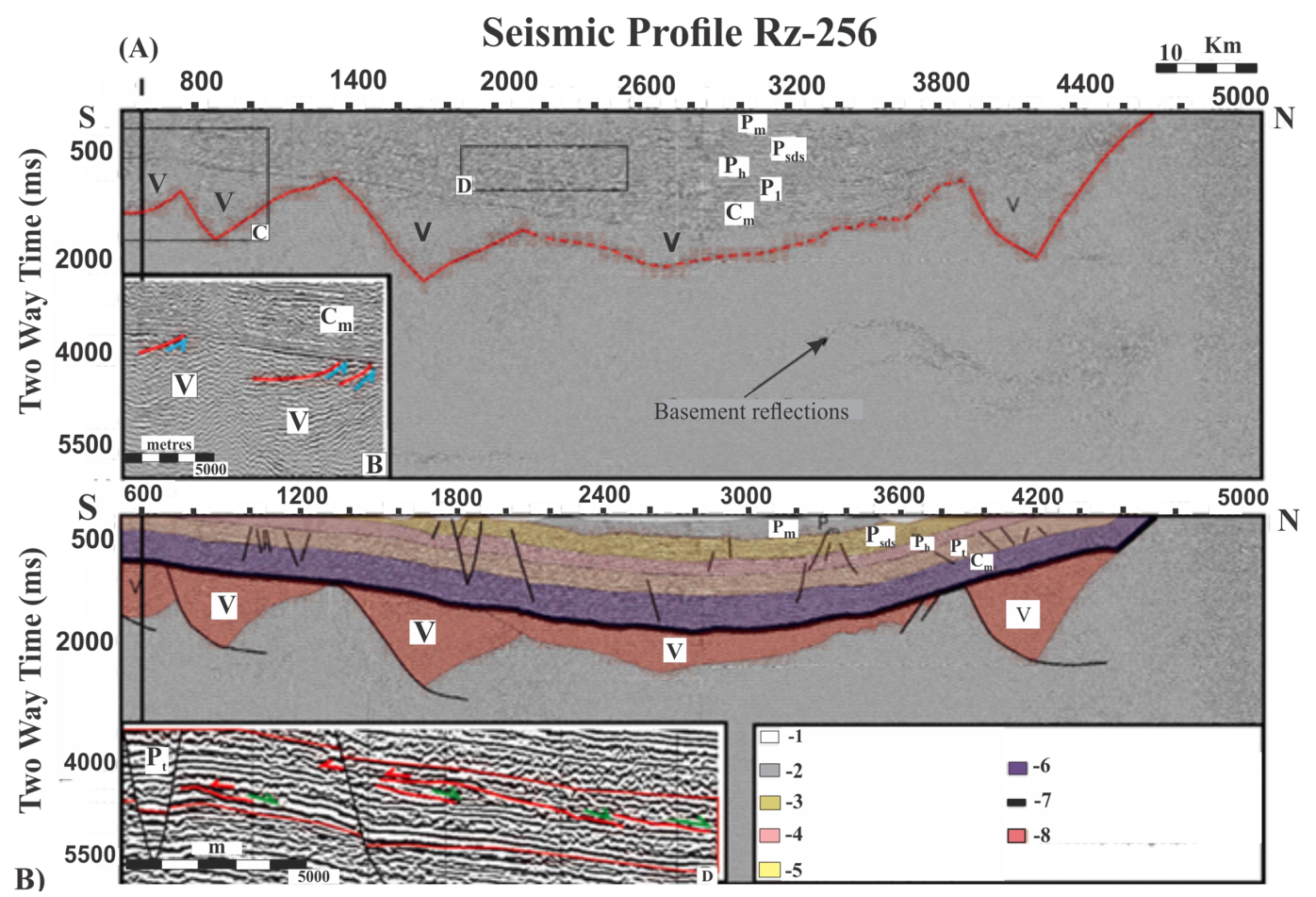

Figure 3. The N-S seismic profile Rz-256 traversing through the study area: A folded and transferred, B - interpretation of figure A. Red line = interface of overlying sediments/basement; dashed line represents indefinite extent of contact. The black lines are normal faults with small graben structures. B - Ventersdorp basinal reflectors are truncated by a black reef quartzite (blue arrows). C - overlap (red arrows) and downward slope (green arrows) of reflectors within the Timball hill and Boshook Formations [Tinker et al., 2002. Lithologic signatures are represented by: 1 - Quaternary sediments (Q), 2 - $P_{m}$, quartzite $\left(R_{3}\right), 3$ - Psds, sandstones and subordinate shales $\left(R_{3}\right), 4-P_{h}$, shales $\left(R_{2}\right), 5-P_{t}$, lava flows, carbonaceous shales, quartzites and diamictites $\left(R_{1}\right), 6-C_{m}$, manganese - bearing dolomites $\left(\mathrm{Ar}_{2}^{m}\right), 7$ - black reef quartzite $\left(\mathrm{Ar}_{1}\right), 8$ - Ventersdorp lava $\left(\mathrm{Ar}_{1}\right)$ [Tinker et al., 2002].

\section{Sampling and Methodology}

A number of exploration pits were opened during stage 1 and stage 2 of exploration at the study site. These formed the basis in understanding the ore sediment accumulation, delineation of the ore stratigraphy of the mine area, and finally the principal source of ore sampling. On the basis of field observations during mapping of the sections, it was then noticed that the section is divisible into various zones which were earlier named: A, B, C, D, E, F, G and $\mathrm{H}$ [Pharoe and Liu, 2018]. For this study 30 samples from four exploration boreholes were used (Figure 5). Samples were firstly prepared into 20 thin and 15 thick sections to be studied under polarized and reflected light. Miner- als which were identified under the petrographic microscope were then analyzed using the Scanning Electron Microscope and X-Ray Diffractometer. Of the 30 samples 16 were analyzed for geochemical constituents with the use of X-ray fluorescence. Scanning Electron Microscopy and Energy Dispersive Spectroscopy analyses were performed on JEOL JSM-6460 LV and JOEL JSM 7001F with Schottky cathode (thermal field emission) models at the Centre of analytical studies in the Saint Petersburg Mining University. The X-ray Diffraction measurements were performed on Shimadzu X-ray diffractometer, XRD 6000 at room temperature of $25^{\circ} \mathrm{C}$. The fine powdered samples were spread on a glass slide and scanned at $2 \Theta /$ minute from $10^{\circ}$ to $60^{\circ}$ in $2 \Theta$ (wavelength $\left.=1.54058\right)$. The remaining powder was subjected to X-Ray Fluorescence 


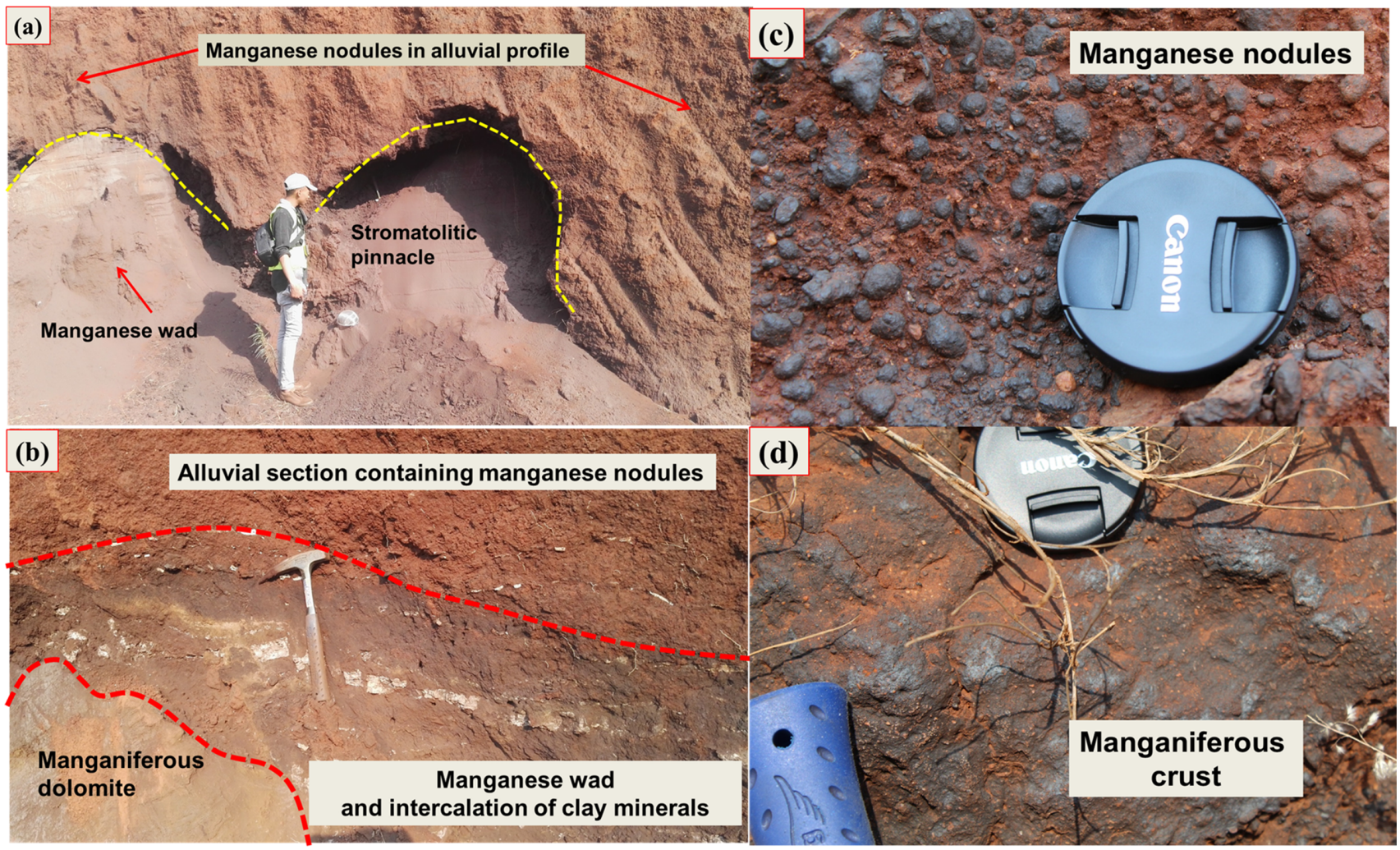

Figure 4. Rock samples of the General Nice Mine Area; a) stromatolitic dolomitic remnant structures, and manganese wad; b) occurrence of manganese in a weathered alluvial succession; c) Mn wad in the saprolite with intercalated layers of clay; d) manganiferous crust.

(XRF) for major and trace element analyses undertaken on MagiX Fast, XRF spectrometer. For major element analysis the milled sample $(<75 \mu \mathrm{m}$ fraction) was roasted at $1000^{\circ} \mathrm{C}$ for at least 4 hours to oxidize $\mathrm{Fe}^{2+}$ and $\mathrm{S}$ and to determine the loss of ignition (L.O.I.). Glass disks were prepared by fusing $1 \mathrm{~g}$ of roasted sample and $10 \mathrm{~g}$ flux consisting of $49.5 \% \mathrm{Li}_{2} \mathrm{~B}_{4} \mathrm{O}_{7}, 49.5 \%$ and $0.50 \% \mathrm{LiI}$ at $1150^{\circ} \mathrm{C}$. Quality Control was done by using an in-house amphibolite reference material (sample 12/76). Also 1 in every 10 samples was duplicated during sample preparation and analyses. For trace element analysis $12 \mathrm{~g}$ milled sample and $3 \mathrm{~g}$ Lico wax was mixed and pressed into a powder briquette using a hydraulic press with the applied pressure at 25 ton. The glass disks and wax pellets were analyzed using a PANalytical wavelength dispersive Axios X-Ray Fluorescence spectrometer equipped with a $4 \mathrm{kw}$ $\mathrm{Rh}$ tube. Section measurements were carried out with the use of $10 \mathrm{~m}$ long tape measure and photographs of each depicted zone were captured with
Canon EOS 600D digital camera to be attached in a report. Vanier calliper was used for measuring diameter sizes.

\section{Results}

\subsection{Mineral Composition}

The manganese ore mineral phases in the area consist mainly of a group of minerals with the common crystal structure given by: $\left[\mathrm{A}^{+}\left({ }^{2+}\right)\left(\mathrm{Mn}_{6}^{4+} \mathrm{Mn}_{2}^{3+}\right) \mathrm{O}_{16}\right]$, where $\mathrm{A}=$ $\mathrm{K}^{+}, \mathrm{Ba}^{2+}, \mathrm{Pb}^{2+}$. These minerals include cryptomelane $\left(\mathrm{K}^{+}\left[\mathrm{Mn}_{6}^{4+} \mathrm{Mn}_{2}^{3+}\right]_{8} \mathrm{O}_{16}\right)$, hollandite $\left(\mathrm{Ba}^{2+}\left[\mathrm{Mn}_{6}^{4+} \mathrm{Mn}_{2}^{3+}\right]_{8} \mathrm{O}_{16}\right)$ and romanechite ((Ba, $\left.\left.\mathrm{H}_{2} \mathrm{O}\right)_{2}\left[\mathrm{Mn}^{4+} \mathrm{Mn}^{3+}\right]_{5} \mathrm{O}_{10}\right)$. Other manganese oxide phases include pyrolusite $\left(\alpha-\mathrm{MnO}_{2}\right)$ and vernadite $\mathrm{Mn}(\mathrm{OH})_{4}$ (Figure 6). Accessory minerals includes iron oxides mainly hematite $\left(\mathrm{Fe}_{2} \mathrm{O}_{3}\right)$ and 


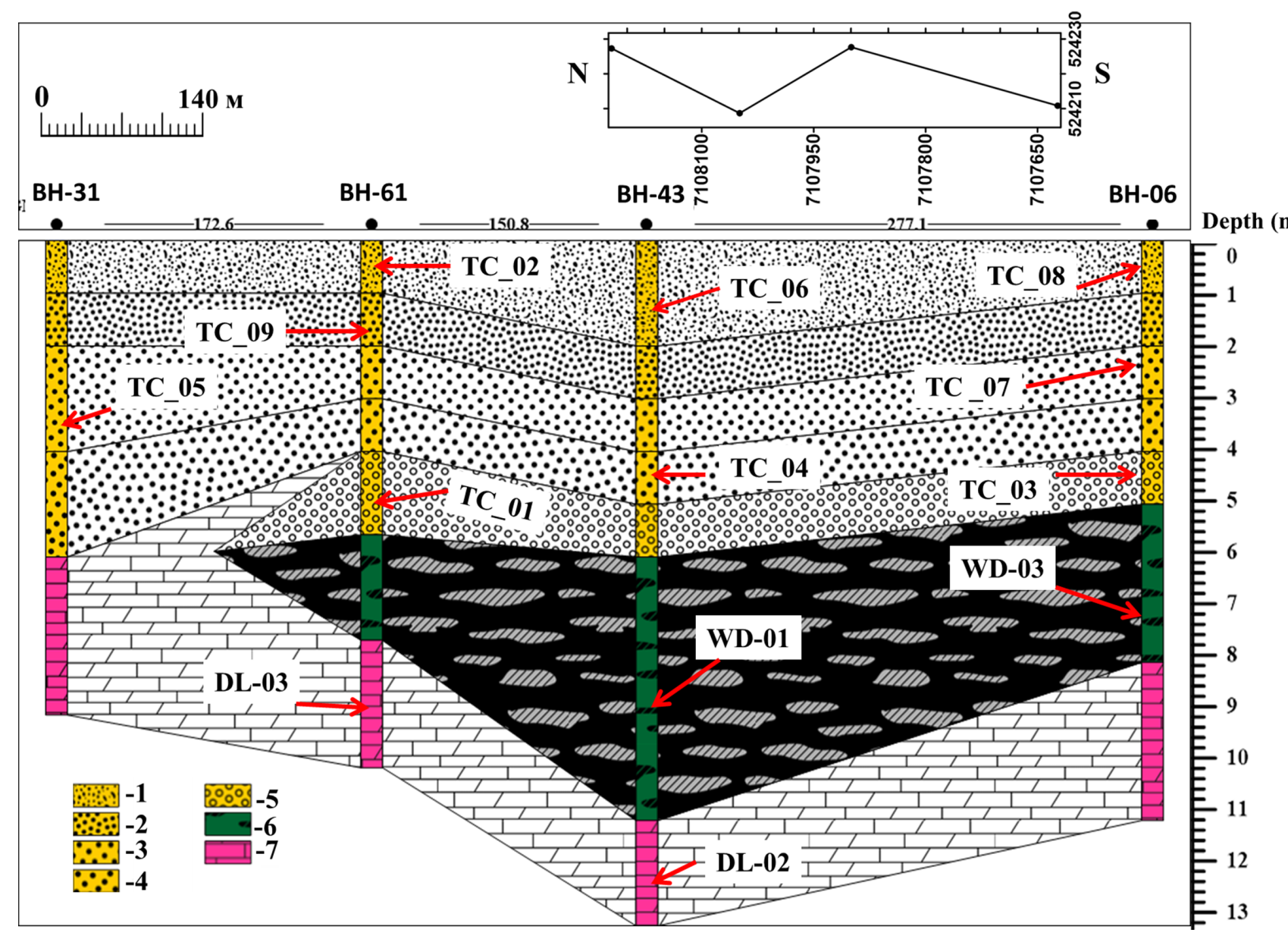

Figure 5. Geological section of the study area which run across boreholes BH-31, BH-61, BH-43 and BH-06; where: 1 - fined grained manganese nodules of the uppermost layer, 2 - fined-medium grained manganese nodules, 3 - medium grained manganese nodules, 4 - coarse grained manganese nodules, 5 - coarsest fraction of manganese nodules with intercalations of calcrete layers, 6 - manganese wad, 8 - manganiferous dolomites.

goethite $[\mathrm{FeO}(\mathrm{OH})]$; inclusions of detrital zircon and ilmenite. Mn oxide phases occur mostly in the form of concentric lamina encircled around the nucleus of other rock fragments. Diagenetic features indicate the replacement of mostly early formed minerals by manganese oxides. These include the replacement of detrital quartz grains in terrigenous fragments by cryptomelane (Figure $7 \mathrm{~g}$ ). The late diagenetic stage is evident from the precipitation of galaxite $(g l x)$ with acicular needle like morphology around the pore spaces (Figure 7a, Figure 7b and Figure 7h). On the SEM micrograph displayed on the left, it is visible that the formation of galaxite has entirely enclosed the pore spaces (Figure $7 \mathrm{a}$ ). This suggests an increase in $\mathrm{Al}$ content within the depository towards the latest diagenetic stage probably from the weathering of carbonaceous shales of the waterval saprolite and terrigenous alluvial sediment. Alteration of pyrolusite and it's replacement by romanechite is also evident, and may be ascribed to a change in the water chemistry of the depository due to an increase $\mathrm{pH}$ from the weathering of dolomites and possibly an increase in the degree of oxidation (Figure 7e). Romanechite (Rom) is seen in the form of vein cross-cutting the ground mass of both cryptomelane (crypt) and pyrolusite (pyr) (Figure 7pFigure 7d). Features of replacement of clay minerals by Mn oxides are also evident (Figure 7 f). The Mn-oxide generation indicates the early stage which characterized by the precipitation of manganese oxyhydroxides from ore solutions, and that 


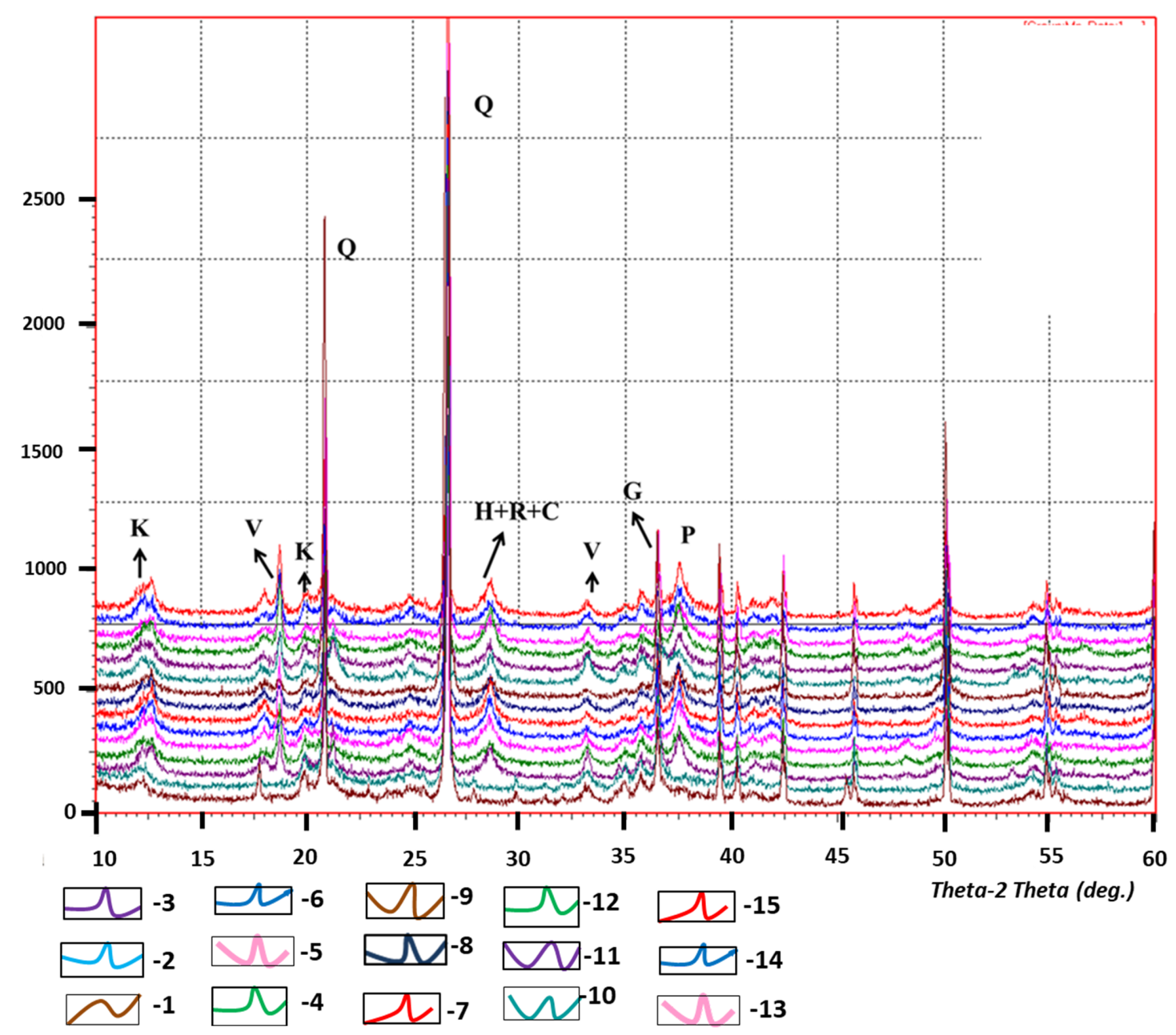

Figure 6. X-ray diffraction spectra showing various mineral phases in the study area; where alphabets indicate the names of these minerals: $\mathrm{C}$ - cryptomelane, $\mathrm{V}$ - vernadite, $\mathrm{R}$ - romanechite, $\mathrm{G}$ - galaxite, $\mathrm{H}$ - hollandite, $\mathrm{P}$ - pyrolusite, $\mathrm{K}$ - kaolinite and $\mathrm{Q}$ quartz. Analyses were carried out on 15 samples: 1 - WD_01, 2 - TC_01, 3 - TC_03, 4 - TC_04, 5 - TC_07, 6 - TC_09, 7 - BH_01, 8 - BH_03, 9 - BH_04, 10 - WD_02, 11 BH_02, 12 - DL_01, 13 - BH_05, 14 - BH_06, 15 - Mn_01.

was followed by formation of high oxidative state manganese oxides; pyrolusite, cryptomelane and romanechite. The formation of the latter minerals was dominated by direct precipitation of $\mathrm{Mn}(\mathrm{IV})$ oxidation state from manganese rich solutions of the weathered Mn protores. The textural relations, especially the acicular morphology which is evident on galaxite, suggest that the minerals have good crystalline structure, achieved by open-space filling.

\subsection{Geochemical Features}

The study of geochemistry of the ore substances assists in determining the genetic features of the ore deposits in supergene zones. Therefore, sam- ples from our collection were analysed for a number of macro-and microelements, including rare earth elements. The results of the analyses are summarized in Table 1. The table shows that all samples have a high content of the following elements: manganese, iron, barium, cobalt, cerium, lanthanum, vanadium, chromium, and nickel. Previously, 8 zones were delineated and mapped out across the sections at open pit areas. These delineations were made based on differences in nodule grain sizes, degree of oxidation, and lithological characteristics within the area [Pharoe and Liu, 2018]. In all the zones, the content of major elements: $\mathrm{MgO}, \mathrm{CaO}$, $\mathrm{K}_{2} \mathrm{O}, \mathrm{Cr}_{2} \mathrm{O}_{3}, \mathrm{P}_{2} \mathrm{O}_{5}$ and $\mathrm{Na}_{2} \mathrm{O}$ oxides is less than $0.1 \mathrm{wt} \%$. In our opinion, the low content of these 

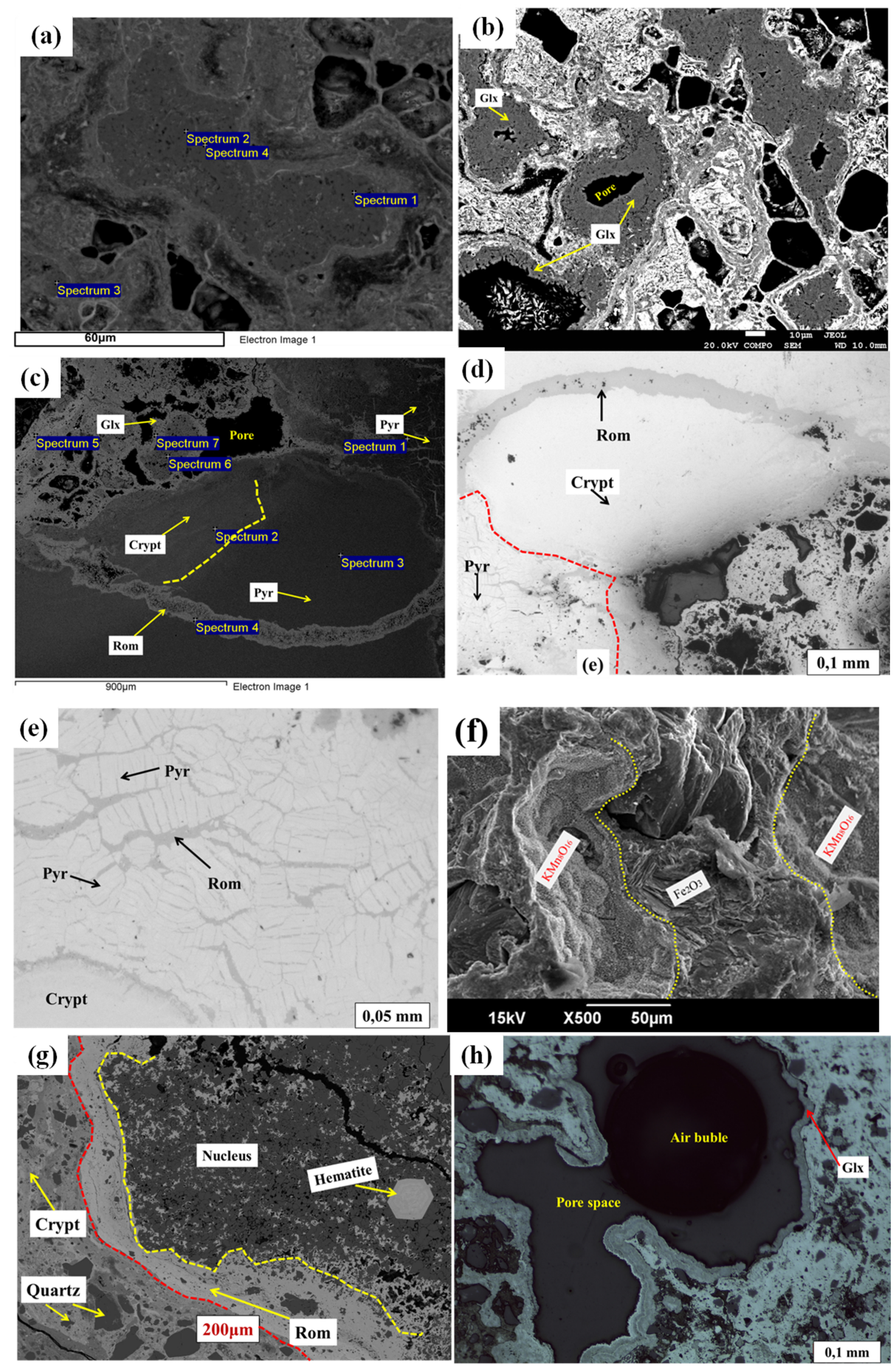

Figure 7. Thin sections and SEM photomicrographs of the studied samples; $a-b)$ The late diagenetic stage of galaxite $(g l x)$ precipitation indicated with acicular-needle like morphology enclosing the pore spaces; c-d) Romanechite (Rom) is seen in the form of vein cross-cutting the ground mass of both cryptomelane (crypt) and pyrolusite $(p y r)$. Thin films of galaxite $(g l x)$ are mostly evident in the form of lining around the pore spaces; e) Alteration of pyrolusite phase indicated with a crack like structural pattern and its replacement by romanechite, f) Pseudomorphic replacement replacement of clay mineral smectite and formation of cryptomelane $\left(\mathrm{KMn}_{8} \mathrm{O}_{16}\right)$ - view under polarizing microscope; g) Manganese oxides mineral phases in the form of lamina around a nucleus fragment; romanechite and cryptomelane on the outer shell - view under polarizing microscope; h) Late diagenetic stage of mineral precipitation is also characterized by precipitation of thin films of galaxite around the pore-spaces - view under polarizing microscope. 


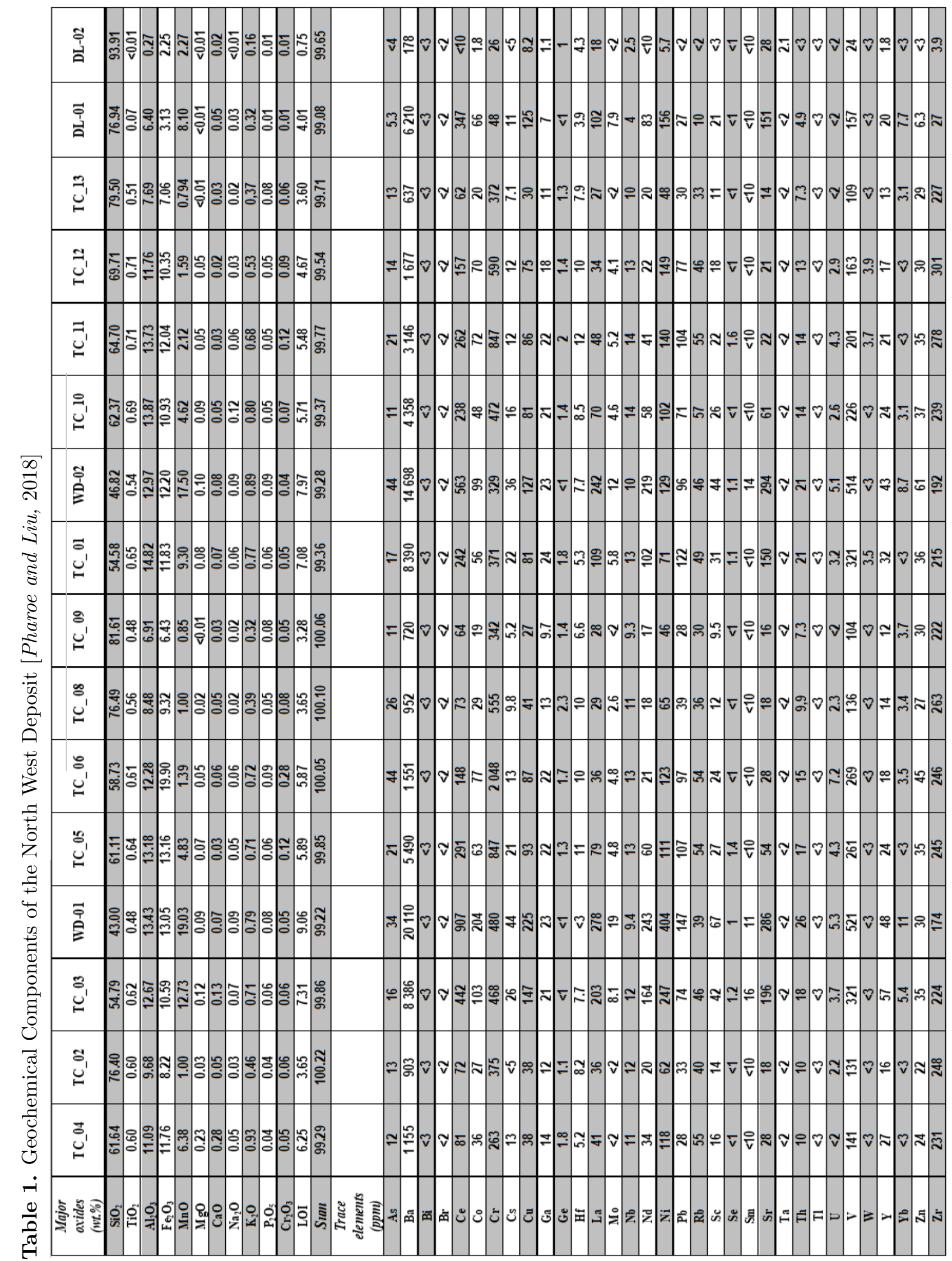


elements is due to the processes of dissolution and leaching by seepage of meteoric water.

Therefore, samples for laboratory analyses were collected from some of those mineralized zones, and the distribution of the main geochemical components of the ore samples across the vertical crosssections in open-pits GNR-BH 37 and GNR-BH 40 are given in Figure 8, The upper zones of the sections contain negligible amounts of manganese oxide ( $\mathrm{MnO}$ ranges from $0.9 \mathrm{wt} \%-1.0 \mathrm{wt} \%$ ), but have elevated content of $\mathrm{SiO}_{2}(77 \mathrm{wt} \%-82 \mathrm{wt} \%)$ and $\mathrm{Fe}_{2} \mathrm{O}_{3}(6.4 \mathrm{wt} \%-9.32 \mathrm{wt} \%)$ and $\mathrm{Al}_{2} \mathrm{O}_{3}(5.6$ wt $\%-8 \mathrm{wt} \%)$. The central zone has the following geochemical components: $\mathrm{SiO}_{2}(43 \mathrm{wt} \%-65$ wt\%), $\mathrm{MnO}$ (1.39 wt\% - 19 wt\%), $\mathrm{Al}_{2} \mathrm{O}_{3}$ (12 wt\% - $13 \mathrm{wt} \%)$ and $\mathrm{Fe}_{2} \mathrm{O}_{2}(13 \mathrm{wt} \%-20 \mathrm{wt} \%)$. The lower zone has elevated concentration of manganese (4.62 wt\% - $17.50 \mathrm{wt} \%$ ), and $\mathrm{Fe}_{2} \mathrm{O}_{2}$ (10 wt\% - 12 wt $\%) . \mathrm{Al}_{2} \mathrm{O}_{3}$ values are ranging between $11 \mathrm{wt} \%$ $14.82 \mathrm{wt} \%$ and $\mathrm{SiO}_{2}$ values are in the at $46.8 \mathrm{wt} \%$ $62.4 \mathrm{wt} \%$ range. Figure 9, Figure 10 and Figure 11 shows the correlation trends between $\mathrm{Mn}$ and trace elements; $\mathrm{Ba}, \mathrm{Ni}, \mathrm{La}, \mathrm{Co}, \mathrm{Ce}, \mathrm{Zr}$ and $\mathrm{Cr}$. These elements with the exception of $\mathrm{Cr}$ and $\mathrm{Zr}$ show a positive strong correlation with $\mathrm{Mn}$, suggesting precipitation from the same ore solutions as $\mathrm{Mn}$. In contrast, $\mathrm{Zr}$ and $\mathrm{Cr}$ were probably sourced from terrigenous sediments, and this is evident from the inclusions of zircon grains in manganese oxide cement.

\section{Discussion}

A number of classification schemes were developed to discriminate the nature of manganese nodule and crust deposits, and their potential metal sources in various geological settings [Achurra et al., 2009, Del Rio Salas et al., 2008. Heshmatbehzadi et al., 2010; Nath et al., 1997, Roy, 1992 , 2006: Sethumadhav et al., 2010; Toth, 1980. Most of these deposits were commonly found to occur in marine and lacustrine environment [Asikainen and Werle, 2007; De Putter et al., 2015, Glasby, 1972, 2006, Lykov et al., 2017, Mero, 1962. In addition to these studies, documentations on supergene enrichment of the oxide phases of these deposits were made in the uplifted and denudated areas, mainly starting from Upper Mesozoic to
Pliocene Period. Traditionally, manganese nodules and crusts are subdivided into hydrogenetic, diagenetic and hydrothermal types. This terminology is strictly based on the type of aqueous fluid from which the Fe-Mn oxyhydr(oxides) precipitates [Bau et al., 2014. Bau et al. 2014 describes the hydrogenetic nodules and crust being deposits which are composed of Fe-Mn oxyhyr(oxides) that precipitated from basin waters as initially colloidal particles within the water column, at the surface of solid substrates or by accretion around nucleus of rock fragments. Diagenetic nodules form from metal ions in sub-oxic pore waters or at the sediment/water interface. Lastly, hydrothermal crusts and nodules are formed from marine medium-low temperature hydrothermal fluids. These latter authors developed an easy but robust classification scheme to discriminate different types of precipitates using graphs of Ce anomaly vs Nd concentration and Ce vs $\mathrm{Y}$ anomalies.

Toth 1980 and Nath et al. 1997 applied the ratio of La vs. Ce to differentiate sources of hydrogenous-supergene and sea water manganese deposits. Based on their classification scheme, La/Ce ratios of 2.8 indicate deposits which fall under marine environment and the La/Ce ratios of equal to 0.25 indicate deposits from supergene enrichment. Nicholson et al. 1997 calculated the $\mathrm{Mn} / \mathrm{Fe}$ ratio to differentiate sources of manganese deposits; where lacustrine deposits have $\mathrm{Mn} / \mathrm{Fe}$ ratio of less than 1 , hydrogenous deposits have $\mathrm{Mn} / \mathrm{Fe}$ ratio of equal to 1 and SEDEX (sedimentary exhalative deposits) with $\mathrm{Mn} / \mathrm{Fe}$ ratio ranging between 0.1 and 10. The construction of these classification schemes and their effectiveness in defining different precipitates of manganese oxyhydr (oxides) in a given geologic setting, owes to the character of manganese oxide minerals, particularly the barium-potassium bearing manganese oxides. These mineral phases are known to comprise of $\sim 4.6 \AA$ tunnel in their structure which enables scavenging and sorption of rare and trace metals during precipitation [Randall et al., 1998.

On the basis of these classification schemes, the North West Manganese Ore Mineralization was inferred to be of supergene and hydrogenous Figure 12 in origin from the in situ weathering and dissolution of the underlying manganiferous Malmani Dolomites and other proto-ores of carbonaceous shales. The ore mineralization occurred in a 

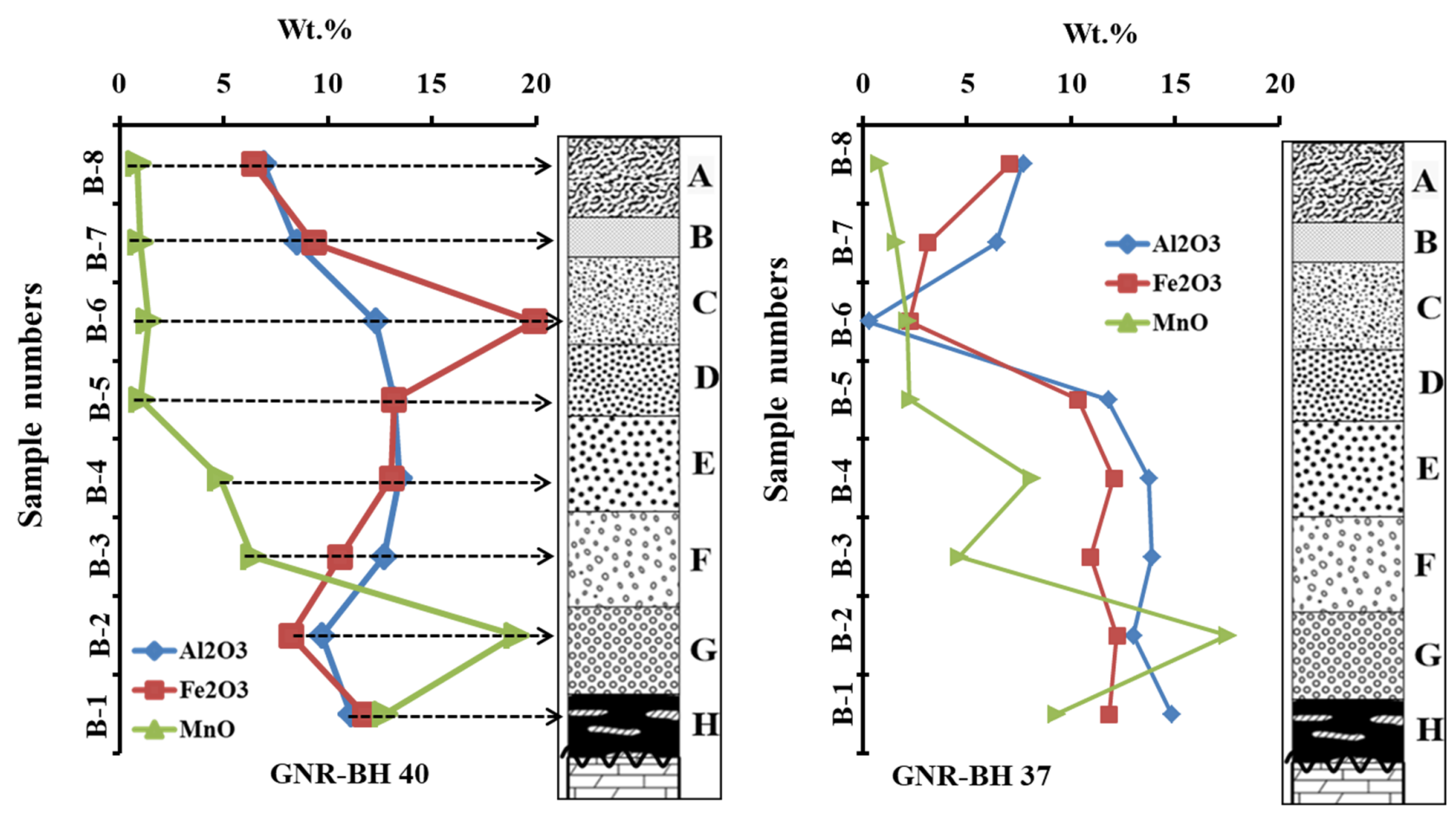

Wt.\%
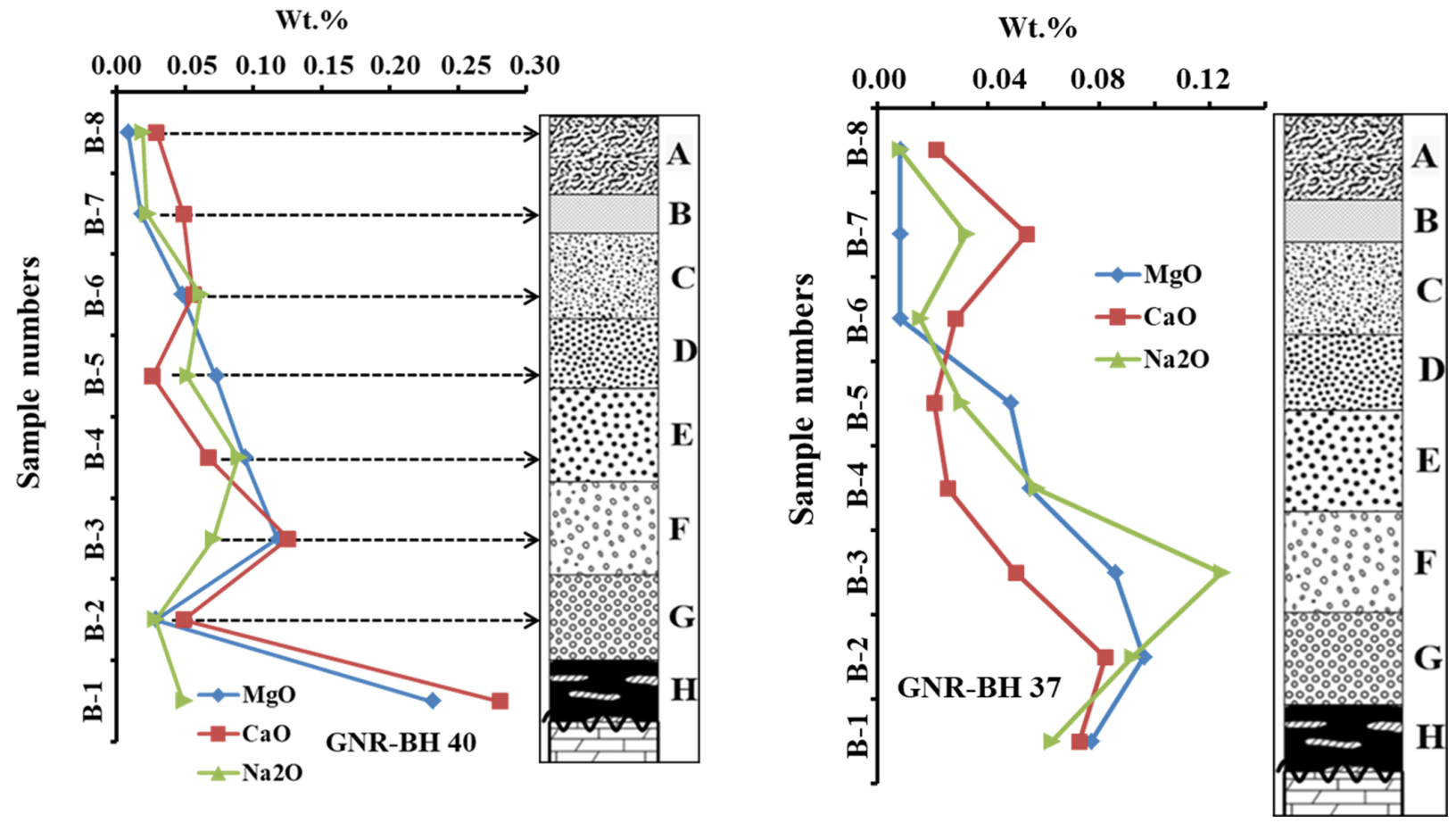

Figure 8. Geochemical components ( $\left.\mathrm{MnO}, \mathrm{Fe}_{2} \mathrm{O}_{3}, \mathrm{Al}_{2} \mathrm{O}_{3}, \mathrm{CaO}, \mathrm{Na}_{2} \mathrm{O}, \mathrm{K}_{2} \mathrm{O}\right)$ along the different sections of the stratigraphy in GNR-BH 40 and GNR-BH 37 [Pharoe and Liu, 2018 .

humid, hot and oxidizing continental setting. This is evident from the occurrence of manganese ores of the mine area within an old weathered continental crust, underlain by the bedrock of Malmani Sub- group. The ore occurs mostly as concentrated manganese wad and nodules comprised of manganese oxyhyr (oxides) and accompanying iron formed in oxidizing conditions. This scenario is further sup- 

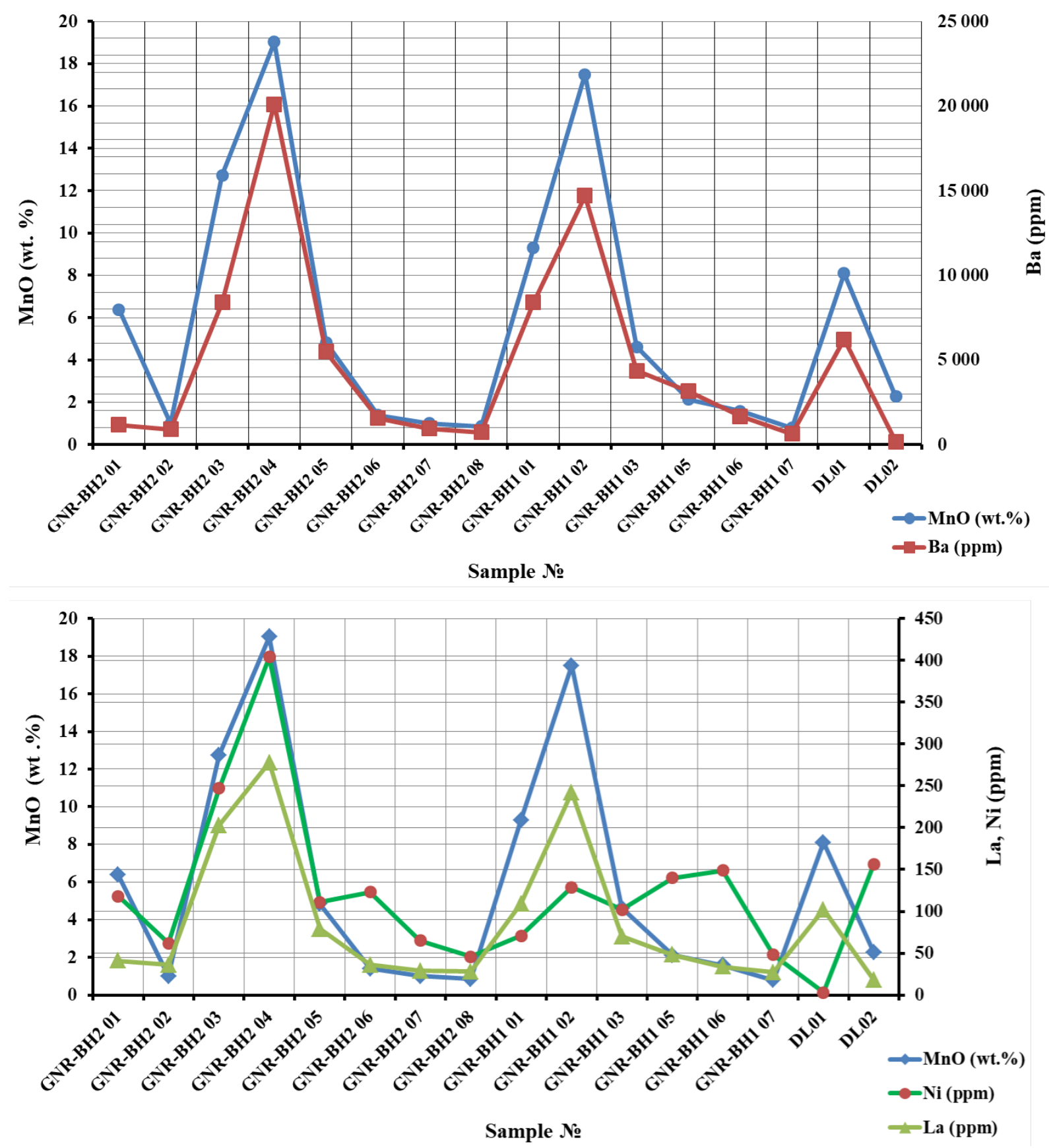

Figure 9. Positive correlation trends between the predominant trace elements: $\mathrm{Ba}, \mathrm{Ni}$, La and Mn.

ported by La/Ce ratio which indicated values ranging between 0.18 and 0.51 for the ore mineralization (Figure 13). The ratio is a representative of supergene deposits and is lower than that of both hydrothermal deposits.

The conceptual geologic mechanism that led to the formation of the General Nice manganese de- posit may be summarized based on the following aspects:

1. The precipitation of Neoarchean-Paleoproterozoic Malmani Dolomite took place in a marine environment; the dolomitic rocks were later enriched in manganese by Mn-Fe rich fluids. 

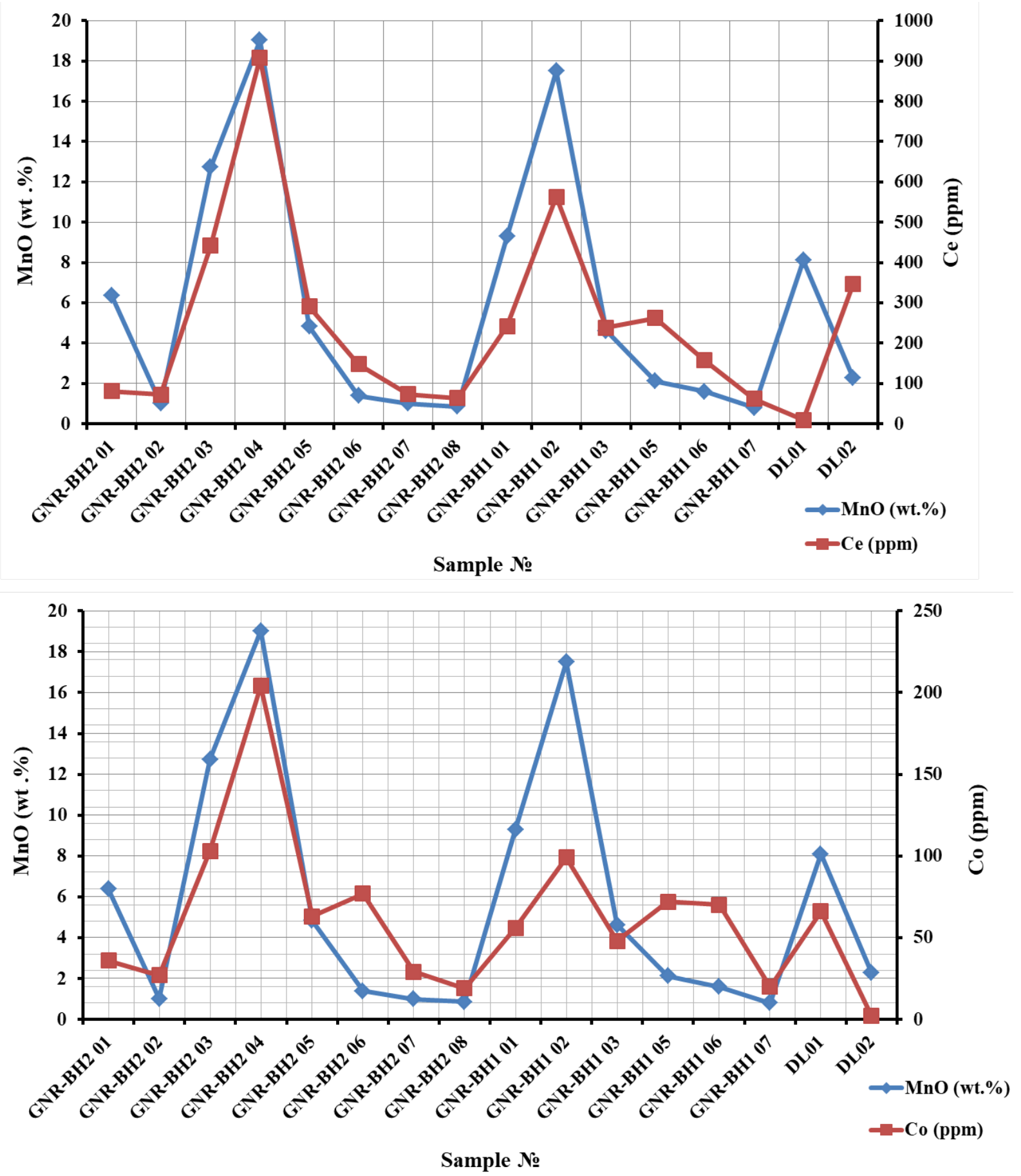

Figure 10. Positive correlation trends between Mn and highly concentrated trace elements (Co and $\mathrm{Ce}$ ) of the North West mineralization.

2. Later on, in the Late Cretaceous to Mid Cenozoic Periods, the African Land Surface was uplifted [Burke and Gunnell, 2008, Partridge and Maud, 1987, exposing Malmani Dolomite to the action of surface meteoric fluids. Subsequent erosion followed (Post African 1 event of Uplift and Erosion) Pack et al. 2000. This geologic episode, characterized by prolonged rainfall resulted in abundant surface water which covered most parts of the landscape forming small lakes due to continuous influx of stream water into the basin. As a resul- 

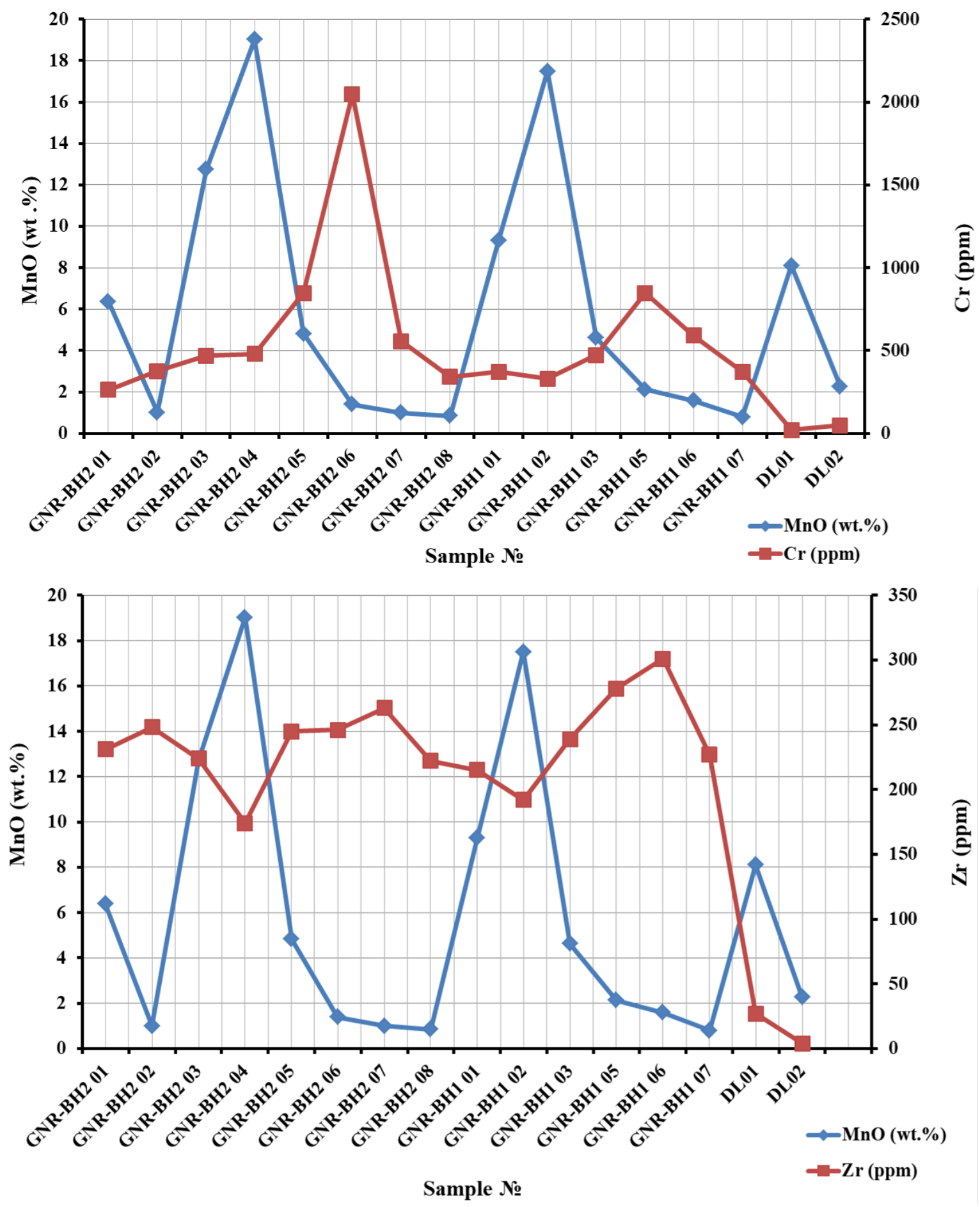

Figure 11. Negative correlation trends between $\mathrm{Mn}$ and trace elements ( $\mathrm{Zr}$ and $\mathrm{Cr}$ ) of the North West mineralization.

tant of such climatic conditions, the exhumed Malmani Dolomites underwent a strong chemical weathering and dissolution in an oxidizing environment which led to leaching out of unstable mineral phases such as Mn-carbonates,
Mn-Fe silicates etc.

3. The weathering of manganiferous dolomites released $\mathrm{Mn}-\mathrm{Fe}$ rich colloidal particles into surface water. River channels continued depositing the sediments (mostly silt and gravel) 

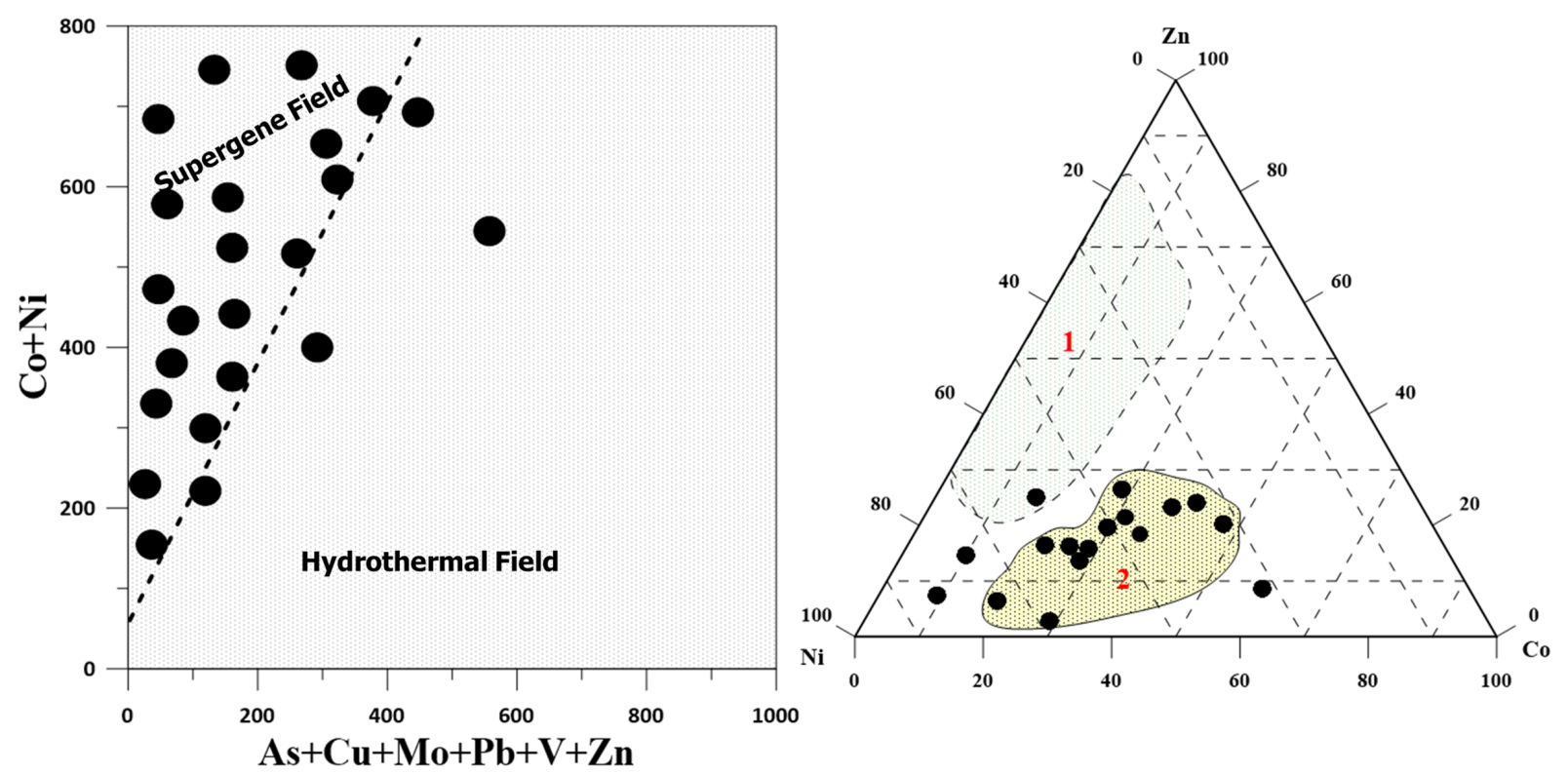

Figure 12. Bivariate and ternary discrimination plots for trace elements indicating the possible sources of manganese based on [Del Rio Salas et al., 2008. Heshmatbehzadi et al., 2010. Where: 1 - hydrothermal field and 2 - hydrogenetic field.

into the flat lying drainage system. These sediments settled in water column based on their specific gravities with silt settling on top of gravels. The process packed sediment column on top of the weathered Malmani Dolomite forming the soil profile across the study area.

4. Dissolved divalent manganese ions are known to be unstable in a high $\mathrm{pH}$ solution $[\mathrm{Hem}$, 1963 , and tend to be oxidized to higher valence state, forming high valence manganese oxide colloids. The colloids were then swept towards and attracted to solid objects, mostly terrigenous sediments which acted as centers of accretion. Hence, the nuclei appear mostly as quartz, quartzite, sand, calcite and Mn-Fe fragments.

\section{Conclusions}

The study employed petrography and geochemical data to reconstruct the genetic model of the North West Manganese Ore Mineralization. The trace element geochemistry coupled with the study of mineralogy and diagenetic features of the ore samples were applied in this study. This enabled the discrimination of sources of ore precipitates through a number of manganese classification sche- mes. The inferences which were made from the data interpretation indicated the supergene and hydrogenetic nature of the ore mineralization suggesting precipitation of ore substances from the weathered colloids (sols) of the manganiferous Malmani dolostones and carbonaceous shales of the lower Malmani series in a continental setting characterized by oxidic conditions and lacustrine environment. The ore formation was facilitated by the uplift of the Southern Africa's Subcontinent which resulted in denudation and exposure of manganiferous dolostones to the action of meteoric fluids in a supergene zone. The ore formation occurred at a passive continental setting which is characterized by warm to humid climatic conditions and an oxidic lacustrine environment.

The deep and intensive chemical weathering and dissolution of manganiferous dolostones along the post-Gondwana African Land Surface occurred during the Late Cretaceous-Mid Cenozoic uplift of the African Landscape. This initially resulted in the formation of Waterval saprolite which is composed of $\mathrm{Mn}$ wad. This geologic time frame was recently confirmed by Vafeas et al. 2018 to be around 77 Ma from dating of apatite inclusion in the supergene ore of the Kalahari Manganese Field. The saprolite later supplied the overlying water column with manganese rich residues and colloids which later precipitated as manganese nodules and lin- 


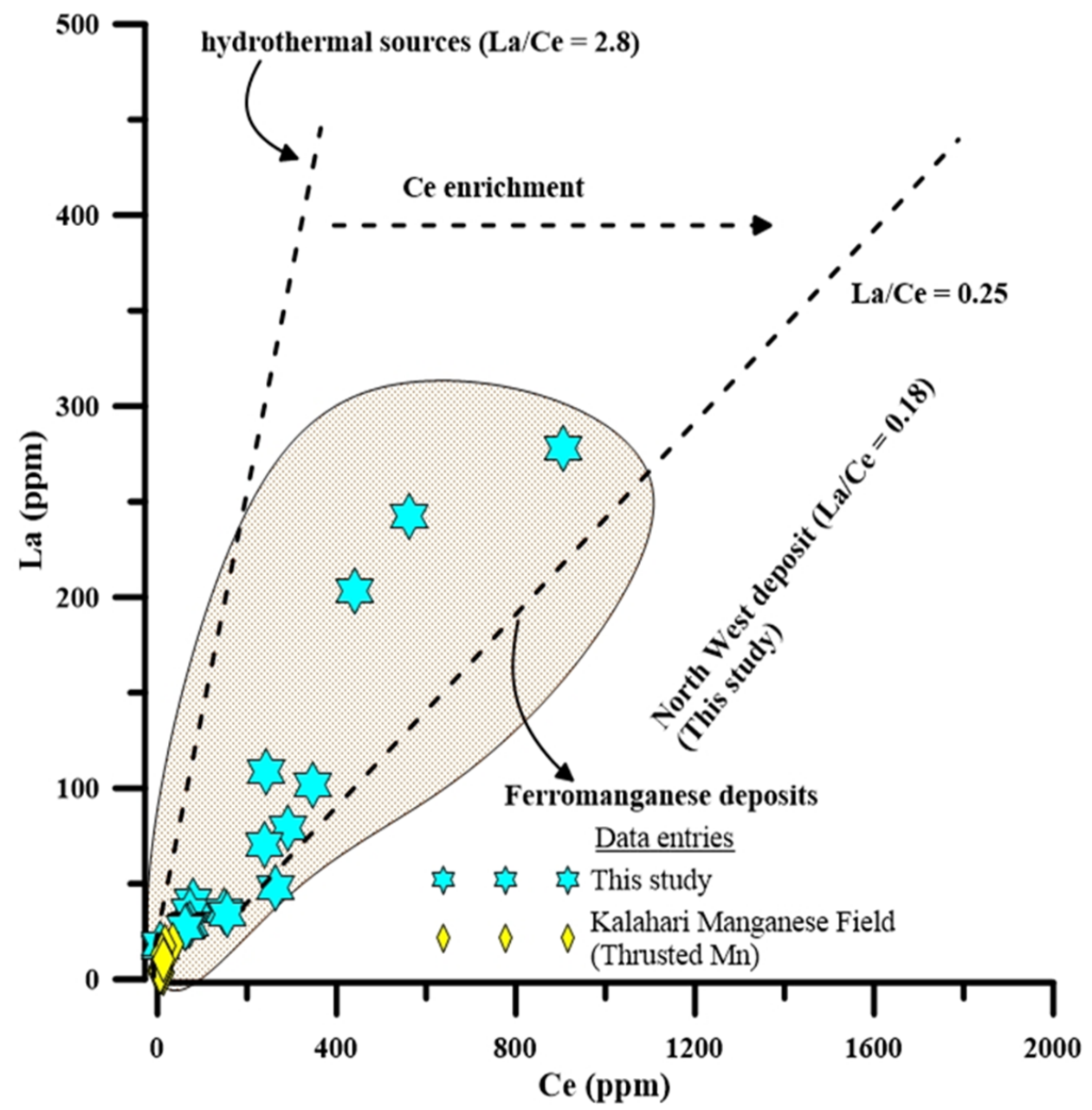

Figure 13. Binary plot of La vs. Ce concentration for the General Nice ore mineralization (after [Nath et al., 1997; Toth, 1980. The Mn/Fe ratio as applied by Nicholson et al. 1997 gives values of up to 0.53 suggesting manganese ore formation from secondary hydrogenetic ore precipitates in a lacustrine water column.

ings around older manganese nodules and alluvial fragments of quartz, quartzite, and sands within the Westwits alluvium. The predominant $\mathrm{Ba}-\mathrm{Mn}$ Oxide (romanechite) indicates that the depository had grown more oxidic and alkaline due to continuous dissolution of manganiferous dolostones upon reaction with acidic meteoric fluids. This setting is in overall comparable to that of other manganese deposits, elsewhere in Africa [Beukes et al., 2016. Colin et al., 2005, De Putter et al., 2015, Van Niekerk et al., 1999a, 1999b.

Acknowledgments. The first author would like to thank the South African Ministry of Education for the provision of research funding which covered the field work and some of the laboratory tests which were carried out for the research. The Ministry of Education in the Russian Federation is acknowledged for funding the registration and stay in the Saint Petersburg Mining University.

\section{References}

Achurra, L. E., J. P. Lacassie, J. P. Le Roux, et al. (2009), Manganese nodules in the Miocene Bahia Inglesa Formation, north-central Chile: Petrography, geochemistry, genesis and palaeoceanographic significance, Sedimentary Geology, 217, 128-139, Crossref

Asikainen, C. A., S. Werle (2007), Accretion of ferromanganese nodules that form pavement in second Connecticut lake, New Hemisphere, Proceeding of the National Academy of Science (PNAS), 104, 17,579-17,581, Crossref

Bau, M., K. Schimdt, A. Koschinsky, et al. (2014), 
Discriminating between different genetic types of marine ferro-manganese crusts and nodules based on rare earth elements and yttrium, Chemical Geology, 381, 1-9, Crossref

Beukes, N. J., H. S. Van Niekerk, J. Gutzmer (1999), Post-Gondwana African land surfaces and pedogenic ferromanganese deposits on the Witwatersrand at the West Wits gold mine, South African Journal of Geology, 102, 65-82.

Beukes, N. J., E. W. Swindell, H. Wabo (2016), Manganese deposits of Africa, Episodes Journal of International Geoscience (IUGS), 39, 285-317, Crossref

Burke, K., Y. Gunnell (2008), The African erosion surface: a continental-scale synthesis of geomorphology, tectonics, and environmental change over the past 180 million years, Geological Society of America: Memoir, 201, 66, Crossref

Colin, F., A. Beauvais, et al. (2005), First $39 \mathrm{Ar}-40 \mathrm{Ar}$ geochronology of lateritic manganiferous pisolites: implications for the Palaeogene history of a West African landscape, Earth Planet Science Letter, 238, 172-188, Crossref

De Putter, T., G. Ruffet, J. Yans, F. Mees (2015), The age of supergene manganese deposits in Katanga and its implications for the Neogene evolution of the African Great Lakes Region, Ore Geology Reviews, $71, \quad 350-362$, Crossref

Del Rio Salas, R., J. Ruiz, L. Ochoa-Landin, et al. (2008), Geology, Geochemistry and Re-Os systematics of manganese deposits from the Santa Rosalia Basin and adjacent area in Baja California Sur, Mexico, International Journal for Geology, Mineralogy and Geochemistry of Mineral Deposits, 43, 467482, Crossref

De Villiers, J. (1960), The manganese deposits of the Union of South Africa: Pretoria, Geological Survey of South Africa Handbook, 2, 263.

Els, B. G., W. A. van den Berg, J. J. Mayer (1995), The Black reef Quartzite Formation in the western Transvaal: Sedimentological and economic aspects, and significance for basin evolution, Mineral Deposita, 30, 112-123, Crossref

Eriksson, P. G., W. Altermann, O. Catuneaunu, et al. (2001), Major influences on the evolution of the 2.67-21 Ga Transvaal Basin, Kaapval Craton, Sedimentary Geology, 141/142, 205-231, Crossref

Frimmel, H. E. (2014), A giant Mesoarchean crustal gold-enrichment episode: possible causes and consequences for exploration, Building exploration capability for the 21st Century, Kelley K., Golden, H. C. (Eds.) p. 209-234, Society of Economic Geologists, Special Publication 18, Crossref

Glasby, G. P. (1972), The mineralogy of manganese nodules from a range of marine environments, Marine Geology, 13, 57-72, Crossref

Glasby, G. P. (2006), Manganese: Predominant role of nodules and crust, Marine Geochemistry, H. D. Schulz and M. Zabel (Eds.) p. 593, Springer Science, Berlin, Heidelberg.
Gutzmer, J., N. J. Beukes (1994), Karst control of the Ryedale $\mathrm{Fe}-\mathrm{Mn}$ deposit in the Palaeozoic Karoo Supergroup, Western Transvaal, South Africa: Berichte der Deutschen Mineralogischen Gesellschaft, Beiheft zum, European Journal of Mineralogy, 6, 333.

Hem, J. (1963), Chemical equilibria affecting the behavior of manganese in natural water, International Association of Scientific Hydrology. Bulletin, 8, No. 3, 30-37, Crossref

Heshmatbehzadi, K., J. Shahabpour (2010), Metallogeny of manganese and ferromanganese ores in Baft Ophiolitic Mélange, Kerman, Iran, Australian Journal of Basic and Applied Sciences, 4, No. 2, 302313.

Lykov, Y. V., V. G. Gorelikov, B. Gantulga (2017), Analytical research and classification of mechanism of diamond drilling-bits contact with rocks during well sinking, IOP Conference Series: Earth and Environmental Science, 87, 6, Crossref

Mero, J. L. (1962), Ocean-floor manganese nodules, Economic Geology, 57, 747-767, Crossref

Nath, B. B., W. L. Pluger, I. Roelandts (1997), Geochemical constraints on the hydrothermal origin of ferromanganese incrustations from the Rodriguez triple junction, Indian Ocean, Geological Society of London, Special Publication, 119, 199-211, Crossref

Nicholson, K., V. K. Nayak, J. K. Nanda (1997), Manganese ores of the Ghoriajhor-Monmunda area, Sundergarh District, Orissa, India: geochemical evidence for a mixed Mn source, Geological Society of London, Special Publication, 119, 117-121, Crossref

Pack, A., J. Gutzmer, N. Beukes, H. Van Niekerk (2000), Supergene ferromanganese wad deposits derived from Permian Karoo Strata along the late Cretaceous-mid-Tertiary African land surface, Ryedale, South Africa, Economic Geology. B, 95, 203-220, Crossref

Partridge, T. C., R. R. Maud (1987), Geomorphic evolution of Southern Africa since Mesozoic, South African Journal of Geology, 90, 197-208.

Pharoe, B. K., K. Liu (2018), Stratigraphy of the pedogenic manganese nodules in the Carletonville area, North West Province of South Africa: A case study of the General Nice Manganese Mine, Journal of African Earth Sciences, 143, 79-101, Crossref Randall, S. M., D. M. Serman, K. V. Ragnarsdottir (1998), An extended X-ray absorption fine structure spectroscopy investigation of cadmium sorption on cryptomelane $\left(\mathrm{KMn}_{8} \mathrm{O}_{16}\right)$, Chemical Geology, 151, 95-106, Crossref

Roy, S. (1992), Environments and processes of manganese deposits, Economic Geology, 87, 12181236.

Roy, S. (2006), Sedimentary manganese Metallogenesis in response to the evolution of the Earth system, Earth Science Reviews, 77, 273-305, Crossref

Sethumadhav, M. S., G. Yanni, et al. (2010), 
Late Archean manganese mineralization and younger supergene manganese ores in the Anmod-Bisgod region, western Dharwar Craton, southern India: Geological characterization, palaeoenvironmental history, and geomorphological setting, Ore Geology Reviews, 38, 70-89, Crossref

Tinker, J., M. de Wit, J. Grotzinger (2002), Seismic Stratigraphic Constraints on Neoarchean-Paleoproterozoic Evolution of the Western Margin of the Kaapvaal Craton, South Africa, South African Journal of Geology, 105, 107-134, Crossref

Toth, J. R. (1980), Deposition of submarine crusts rich in manganese and iron, Geological Society of America Bulletin, 91, 44-54, Crossref

Vafeas, N. A., L. C. Blignaut, K. S. Viljoen (2018), New evidence for the early onset of supergene alteration along the Kalahari unconformity, South African Journal of Geology, 121, 157-170, Crossref

Vafeas, N. A., L. C. Blignaut, K. S. Viljoen (2019), Arsenic-bearing manganese ore of the Mukulu Enrich- ment in the Kalahari Manganese Field, South Africa: A new discrimination scheme for Kalahari manganese ore, Ore Geology Reviews, 115, 1-12, Crossref

Van Niekerk, H.S., N. J. Beukes, J. Gutzmer (1999a), Post-Gondwana pedogenic ferromanganese deposits, ancient soil profiles, African land surfaces and palaeoclimate change on the Highveld of South Africa, Journal of African Earth Sciences, 29, 761-781, Crossref

Van Niekerk, H. S., J. Gutzmer, N. J. Beukes, et al. (1999b), An ${ }^{40} \mathrm{Ar} /{ }^{39} \mathrm{Ar}$ age of supergene K-Mn oxyhydroxides in a post-Gondwana soil profile on the Highveld of South Africa, South African Journal of Science, 85, 450-454.

\section{Corresponding author:}

Benedick Kinshasa Pharoe, St.-Petersburg Mining University, 21 Line, No. 2, 199106, St.-Petersburg, Russia. (benedictpharoe1@gmail.com) 